\title{
Nutritional and anti-nutritional composition of flour made from plantain and banana hybrid pulp and peel mixture
}

\author{
Adeniji, T.A. ${ }^{1 *}$, Sanni, L.O. ${ }^{2}$, Barimalaa, I.S. ${ }^{1}$, and Hart, A.D. ${ }^{1}$ \\ ${ }^{1}$ Department of Food Science and Technology, Rivers State University of Science and Technology, \\ P.M.B. 5080, Nkpolu, Port Harcourt, Nigeria. \\ ${ }^{2}$ International Institute of Tropical Agriculture, High Rainfall Station, Onne, \\ P.M.B. 008, Nchia-Eleme, Port Harcourt, Nigeria. \\ *Address for correspondence: E-mail: tiradeniji@yahoo.com,
}

ABSTRACT

\begin{abstract}
The nutritional and anti-nutritional constituents of flour made from the entire fruit (pulp and peel) of new plantain and banana hybrids were appraised. Result shows that both PITA $14(2.96 \%)$ and PITA $26(2.79 \%)$ differed significantly $(\mathrm{p}<0.05)$ from other cultivars in moisture. PITA 24 was significantly different from other cultivars in protein (5.46\%), sugar (5.39\%) and ash (5.19\%). Both PITA $17(72.79 \%)$ and BITA $3(72.38 \%)$ differed significantly $(p<0.05)$ from other cultivars $(p<0.05)$ in starch. The reference, Agbagba, was significantly different $(\mathrm{p}<0.05)$ from all the hybrids $(28.59 \%)$ in amylose. Two plantain hybrids, PITA 17 (1.65\%) and PITA 26 (1.62\%) differed significantly $(\mathrm{p}<0.05)$ from other cultivars in fat. Blanching had a significant effect on the nutrients as protein in control $(4.61 \%)$ differed significantly $(\mathrm{p}<0.05)$ from treated fingers. Cold-water treatment $(73.29 \%)$ and fingers blanched at $100^{\circ} \mathrm{C}$ for $10 \mathrm{~min}(73.15 \%)$ had a significant $(\mathrm{p}<0.05)$ effect on the starch content of new Musa flour. Cold-water treatment also had significant effect on sugar $(2.49 \%)$ and fat (1.49) content of Musa flour. The amylose obtained in blanched fruit $(5 \mathrm{~min})$, differed significantly $(\mathrm{p}<0.05)$ from
\end{abstract}

\section{INTRODUCTION}

Plantains and other cooking bananas (Musa spp.), staple food grown throughout the tropics, constitute a major source of carbohydrates for millions of people in Africa, the Caribbean, Latin America, Asia and the Pacific (FAO, 1989; United Nations, 1991; those treated for $10 \mathrm{~min}$, but similar to cold water treated fingers and the control. The ash content of 5-min blanched fingers, cold water and that of control were significantly different $(p<0.05)$ from 10-min blanched fingers. PITA 17 differed significantly $(\mathrm{p}<0.05)$ from other cultivars in saponin $(2.9 \%)$. Tannin and oxalate contents of various cultivars ranged from $0.09-0.36 \%$ and $0.64-0.88 \%$, respectively. PITA 24 differed significantly $(\mathrm{p}<0.05)$ in phytate $\left(9.3 \times 10^{-5} \%\right)$ compared to other cultivars. PITA 24 and Agbagba are significantly different $(\mathrm{p}<0.05)$ in cyanide $\left(8.0 \times 10^{-5} \%\right)$ compared to the rest of the varieties. Phenolics found in the new hybrids and landrace ranged between 0.04-0.06\%. Lead and cadmium content of different varieties ranged from $0.03-0.14 \%$ and $0.02-0.04 \%$, respectively, but no significant difference $(p>0.05)$ was found among the cultivars in mercury $(<0.01 \%)$. This new data suggests that whole flour from new cultivars of plantain and banana hybrid may constitute an important food or feeding stuff from the point of view of their nutritional potentials and low levels of anti-nutrient and heavy metals.

Key words: Nutritional, anti-nutritional, hybrid, flour, pulp, peel. 
(Adeniji, 1995; Berry, 1992). Rahman (1963) reported on the use of whole plantain fruit, consisting of both pulp and peel in flour production, while the peels and trunk are utilised for various agricultural purposes (Ketiku, 1973; Ankrah, 1974). In Nigeria, Cameroon, Cote d'Ivoire and other plantain producing countries in Africa, the entire fruit or pulps of unripe or half-ripe plantain are roasted on heated charcoal. The resultant product is usually consumed with other delicacies such as roasted plums, avocado, roasted fish, or meat kelat, and sometimes with combination of hot stew. Unripe plantain is traditionally processed into flour in Nigeria (Ukhum and Ukpebor, 1991) and in other West and Central African countries. Plantain flour is usually mixed with boiling water to prepare an elastic pastry (amala in Nigeria and foufou or fufu in Cameroon), which is eaten with various sauces. Flour made from partially ripe plantain has been used in making biscuit, and instant flour (Ngalani and Crouzet, 1995). Adeniji and Empere (2001) also investigated on the use of $100 \%$ cooking banana flours in making cake, which were acceptable to representatives of consumers in Nigeria. The use of plantain peel in both biogas (methane) production and soap manufacturing has been reported (Ogazi, 1998), indicating waste to wealth prospect in plantain and banana production.

Tannins, oxalates, saponins are among secondary metabolites found in plants (Mahato et al., 1982; Ooning et al., 1996; Duncan et al., 2000). Report on deleterious effects of anti-nutrient in foods has been widely documented (Duhan et al., 1989; Van der Poel, 1990; Noonan and Savage 1999). The nutritional value of Musa spp. fruits varies with cultivar, stage of ripeness, soil, and climatic conditions under which the fruits were cultivated (Chandler, 1995; Baiyeri, 2000; Baiyeri and Unadike, 2001). Improved plantain and banana hybrids is anticipated to have some concentration of anti-nutrient and heavy metals which could hinder the efficient utilisation, absorption or digestion of nutrients and thus, reduce their bio-availability and their nutritional qualities. Research has revealed some anti-nutritional factors present in plantain and banana, but there is no published report on the nutritional, anti-nutritional, and heavy metal status of whole flour obtained from both pulp and peels of new Musa hybrids being currently disseminated in Nigeria. The development of whole flour from new plantain and banana hybrids is anticipated to be a rapid method of flour production, aimed at improving the economic importance of the crops, with improved levels of nutrients, especially minerals, which are concentrated in the peel (Izonfuo and Omuaru, 1988). Whole flour could be prepared into traditional dishes and may also constitute important raw materials in food and feeding stuff formulation. Processing of fresh fruit into flour has a number of advantages, including preservation, price stability, wider availability, and stimulation of agricultural production through market expansion (Ogazi, 1998). Plantain is a multipurpose crop, because the fruit can be utilised at all stages of ripening. Several benefits are derivable from whole plantain or banana flour processing, including economic, time, and nutrient. This new research is therefore aimed at providing information on the nutritional and anti-nutritional profiles of new Musa hybrids, which may hitherto constitute an effective delivery approach, optimise crop utilisation, economy and nutritional benefit.

\section{MATERIALS AND METHODS}

The new cultivars of plantain and banana hybrids released to farmers in Nigeria, and many parts of West and Central Africa (WCA) and East and Southern Africa (ESA) were investigated. The cultivars included four plantain hybrids (PITA 14, PITA 17, PITA 24 and PITA 26), one cooking banana hybrid, BITA 3, with an African plantain landrace, Agbagba, as reference cultivar. Samples were obtained from the experimental station of the International Institute of Tropical Agriculture (IITA), High Rainfall Station, Onne agro ecology, located 
on Latitude $04^{\circ} 43^{\prime} \mathrm{N}$, Longitude $07^{\circ} 01^{\prime} \mathrm{E}$ and $10 \mathrm{~m}$ Altitude, near Port Harcourt, Nigeria. Representative fruit samples were collected from the second hand from the proximal end of the bunch following the recommendation of Baiyeri and Ortiz (2000) the same day the bunch was harvested. Whole plantain flour (WPF) and whole banana flour (WBF) was produced from a combination of pulp and peel mixture. Fruit samples were sliced longitudinally into two halves and further cut into small sizes with the aid of stainless steel kitchen knife and placed in petri dishes and covered with filter paper to prevent contamination. Blanching was carried out on some aliquot samples by dipping fingers in hot water at $100^{\circ} \mathrm{C}$ for 5 and $10 \mathrm{~min}$ before peeling. Fingers were also dipped in cold water after peeling to prevent browning, while some samples were peeled and dry directly, which served as control. Samples were dried in Forced-Air Sanyo Gallenkamp Moisture Extraction Oven at $65^{\circ} \mathrm{C}$ for about $48 \mathrm{~h}$ and milled with the aid of stainless Kenwood Chef Warring Blender, Model KM001 (0067078) series. Proximate chemical composition was determined using AOAC (1990) procedures. The anti-nutrient and heavy metals were determined using the procedure described by Allen et al., (1984). All chemical analyses were performed in the Plant Anatomy and Physiology Research Laboratory, Faculty of Science, University of Port Harcourt, Herbarium, Nigeria.

\section{Data Analysis}

The data generated were analysed using Statistical Analysis Systems version 9.1 SAS (2003) software package. Significance of treatment means was tested at 5\% probability level using Duncan's New Multiple Range Test (DNMRT).

\section{RESULTS AND DISCUSSION}

The proximate compositions of WPF and WBF from new Musa hybrids are presented in Table 1, which shows that both PITA 14 (2.96\%) and PITA $26(2.79 \%)$ differed significantly $(\mathrm{p}<0.05)$ from other cultivars in moisture. The moisture content of extruded plantain snacks $(5.1-5.9 \%)$ reported by Chukwu et al (1998) and 8\% (Adeniji et al., 2006) obtained in plantain and banana hybrids is higher than the present values. The lower the moisture contents in a product the longer the potential storage life. The moisture content obtained in the whole Musa flour may be considered adequate for storage since growth of microorganisms, food spoilage agents, are hindered at such moisture levels. Edelmiro et al. (1977) and Ogazi and Jones (1990) reported that $10 \%$ moisture content in flour is ideal for good keeping quality. A significant difference existed between PITA 24 in protein $(5.46 \%)$, sugar (5.39\%) and ash (5.19\%) compared to other cultivars. Both PITA $17(72.79 \%)$ and BITA 3 $(72.38 \%)$ differed from other cultivars significantly $(\mathrm{p}<0.05)$ in starch. The reference, Agbagba, was significantly different $(\mathrm{p}<0.05)$ from all the hybrids $(28.59 \%)$ in amylose. Two plantain hybrids, PITA $17(1.65 \%)$ and PITA $26(1.62 \%)$ differed significantly $(p<0.05)$ from other cultivars in fat. The protein content obtained in green plantain peel (7.2\%) and pulp (4.0\%) by Izonfuo and Omuaru (1988) is in consistent with this present data. These authors also reported higher level of crude protein, crude fibre, fat, ash and moisture in the plantain peel compared to the pulp. The present data is lower than $5.8 \%$ fat and $9.3 \%$ ash reported in green plantain peel, but in consonance with $2 \%$ fat and $1.8 \%$ ash earlier found in green pulp, according to Izonfuo and Omuaru (1988). Lower levels of fat in WPF and WBF probably give a higher probability of a longer shelf life in terms of the onset of rancidity (Chukwu, et al., 1998). Blanching had no effect on the moisture content of the new Musa hybrids and the Agbagba check (Table 2). The protein content in the control $(4.61 \%)$ differed significantly $(\mathrm{p}<0.05)$ from treated fingers. Cold-water treatment (73.29\%) and fingers blanched at $100^{\circ} \mathrm{C}$ for $10 \mathrm{~min}$ $(73.15 \%)$ had a significant effect $(\mathrm{p}<0.05)$ on starch content of whole Musa flour. Cold water treatment 
also had significant effect on sugar $(2.49 \%)$ and fat $(1.49 \%)$ content. The amylose obtained in fingers blanched for $5 \mathrm{~min}$, differed significantly $(\mathrm{p}<0.05)$ from those treated for $10 \mathrm{~min}$, but similar to cold water treated fingers and the control. The ash content of 5-min blanched fingers, cold water and that of control differed significantly $(\mathrm{p}<0.05)$ from fingers blanched for $10 \mathrm{~min}$. Ahenkora, et al., (1996) reported that boiling and frying results in losses of certain minerals in plantain including iron, copper and zinc.

Anti-nutrients found in whole Musa flour is presented in Table 3, which showed a significant difference $(\mathrm{p}<0.05)$ between PITA 17 and other cultivars in saponin $(2.9 \%)$. The saponin concentration of whole Musa flour, which ranged from $1.03-2.9 \%$ is higher than previous $0.023 \%$ obtained in bitter leaf (Apena et al., 2004). Saponins are practically non-toxic to man when taken orally (Merck, Index (1976), and this anti-nutrient can lower plasma cholesterol concentrations (Oakenfull, et al., 1979 and Topping, et al., 1980). The tannin $(0.36 \%)$ and oxalate $(0.88 \%)$ content of PITA 26 differed significantly $(\mathrm{p}<0.05)$ from other cultivars. Phytate content differed significantly $(\mathrm{p}<0.05)$ in PITA $24\left(9.3 \times 10^{-5} \%\right)$ compared to other cultivars. Phytic acid and tannin content of un-defatted raw Curcurbita pepo (pumpkin, locally known as "eweroko" and "ugboguru" in the Western and Eastern states of Nigeria respectively) are $0.21 \%$ and $0.24 \%$, respectively (Ihediohanma et al., 2004). This suggests that the phytate content in the new plantain and banana hybrids are lower than these values. PITA 24 and Agbagba had a significant difference $(\mathrm{p}<0.05)$ in cyanide $\left(8.0 \times 10^{-5} \%\right)$ compared to the others. All the cultivars were significantly different $(\mathrm{p}<0.05)$ in phenolics $(0.06 \%)$ when compared to PITA26 (0.04\%).

Heavy metals in the new Musa hybrids (Table 4) show that PITA26 and Agbagba had lead content of $0.14 \%$ each, which differed significantly $(\mathrm{p}<0.05)$ from other cultivars. PITA 17 and BITA 3 differed significantly $(\mathrm{p}<0.05)$ from other cultivars in cadmium, while no significant difference $(\mathrm{p}>0.05)$ was found in the mercury content $(<0.01 \%)$ of various cultivars. These are in agreement with $0.01 \mathrm{mg} / \mathrm{kg}$ to $0.006 \mathrm{mg} / \mathrm{kg}$ Lead, Cadmium, Mercury and Chromium levels reported in some sea foods in Rivers State waters in Nigeria (Wordu, 2004). Similarly, Lead and Cadmium levels of 0.013$0.017 \mathrm{mg} / \mathrm{kg}$, and $0.036-0.043 \mathrm{mg} / \mathrm{kg}$, respectively, have been reported in coal and sediments from River Ekulu of Enugu, Coal City State in Nigeria (Adaikpoh, et al., 2005).

\section{CONCLUSION}

The nutritional value of whole flour made from new plantain and banana hybrids were studied. The levels of anti-nutritional factors found in the whole flours may probably be assumed non-toxic. Three major outstanding benefits of this project may include rapid flour production, economic gains as well as increased nutritional benefit. Ogazi (1998) reported that blanched plantain fruits can be hand peeled at the rate of $1000 \mathrm{~kg}$ fruit in $24 \mathrm{man}-\mathrm{h}$, and without blanching, this amount takes 72 man-h to peel. The rate of production, though, not taken into cognisance in the present study, however, it is most likely that less time will be required since fruits were only sliced length-wise and dried, rather than passing through the process of tedious peelings. However, blanching, though, had effect on some of the nutrient in the flour, the effect of different methods applied was inconsistent. This new data therefore suggests that new processing technology should evolve to make plantain and banana fruit more nutritious and usable, when considering the enormous component of fruit that constitute waste. Probably the area with greatest potential for improving technologies is in the use of the so-called inedible portions such as peels, peduncles, pseudostem and leaves. 


\section{ACKNOWLEDGEMENT}

This research would not have been accomplished if not for assistance given by the International Institute of Tropical Agriculture (IITA) in fruit supply and laboratory facilities.

Table 1. Proximate composition of whole flour made from improved plantain and banana hybrids pulp and peel mixture

\begin{tabular}{|c|c|c|c|c|c|c|c|}
\hline \multirow[t]{2}{*}{ Cultivar } & MC & Protein & Starch & Sugar & Amylose & Fat & Ash \\
\hline & \multicolumn{7}{|c|}{$\%$} \\
\hline PITA 14 & $2.96^{\mathrm{a}}$ & $4.38^{\mathrm{cd}}$ & $74.09^{a}$ & $1.67^{\mathrm{b}}$ & $20.58^{\mathrm{b}}$ & $1.44^{\mathrm{b}}$ & $3.96^{\circ}$ \\
\hline PITA 17 & $2.22^{\mathrm{b}}$ & $4.48^{\mathrm{bc}}$ & $72.79^{a}$ & $1.07^{\mathrm{cd}}$ & $22.49^{b}$ & $1.65^{\mathrm{a}}$ & $3.41^{\mathrm{d}}$ \\
\hline PITA 24 & $1.57^{\mathrm{c}}$ & $5.46^{\mathrm{a}}$ & $68.29^{b c}$ & $5.39^{\mathrm{a}}$ & $17.17^{\mathrm{c}}$ & $1.49^{\mathrm{ab}}$ & $5.19^{\mathrm{a}}$ \\
\hline PITA 26 & $2.79^{a}$ & $4.34^{\mathrm{d}}$ & $66.58^{c}$ & $1.58^{\mathrm{bc}}$ & $20.11^{\mathrm{bc}}$ & $1.62^{\mathrm{a}}$ & $4.43^{b}$ \\
\hline BITA 3 & $1.61^{\mathrm{c}}$ & $4.52^{b}$ & $72.38^{\mathrm{a}}$ & $0.64^{\mathrm{d}}$ & $22.0^{\mathrm{b}}$ & $1.36^{\mathrm{b}}$ & $3.91^{\circ}$ \\
\hline AGBAGBA & $1.26^{\mathrm{c}}$ & $3.69^{\mathrm{e}}$ & $70.93^{\mathrm{ab}}$ & $0.52^{\mathrm{d}}$ & $28.59^{a}$ & $0.85^{\mathrm{c}}$ & $3.36^{\mathrm{d}}$ \\
\hline
\end{tabular}

MC=Moisture Content .

Values in the same column with different letters are significantly different at $p<0.05$.

Table 2. Effect of blanching on proximate composition of whole flour made from improved plantain and banana hybrids pulp and peel mixture

\begin{tabular}{|c|c|c|c|c|c|c|c|}
\hline Cultivar & MC & Protein & Starch & Sugar & Amylose & Fat & Ash \\
\hline & & & & $\%$ & & & \\
\hline HW-10 & $1.99^{\mathrm{a}}$ & $4.39^{b}$ & $73.15^{\mathrm{a}}$ & $1.55^{\mathrm{b}}$ & $19.62^{\mathrm{b}}$ & $1.32^{\mathrm{b}}$ & $3.66^{\mathrm{b}}$ \\
\hline HW-5 & $1.91^{\mathrm{a}}$ & $4.42^{\mathrm{b}}$ & $70.29^{b}$ & $1.79^{\mathrm{b}}$ & $23.11^{\mathrm{a}}$ & $1.33^{\mathrm{b}}$ & $4.04^{\mathrm{a}}$ \\
\hline $\mathrm{CW}$ & $2.13^{\mathrm{a}}$ & $4.49^{b}$ & $73.29^{\mathrm{a}}$ & $2.49^{\mathrm{a}}$ & $22.25^{\mathrm{ab}}$ & $1.49^{\mathrm{a}}$ & $4.17^{\mathrm{a}}$ \\
\hline $\mathrm{C}$ & $2.25^{\mathrm{a}}$ & $4.61^{\mathrm{a}}$ & $66.64^{c}$ & $1.43^{\mathrm{b}}$ & $22.31^{\mathrm{ab}}$ & $1.47^{\mathrm{ab}}$ & $4.30^{a}$ \\
\hline
\end{tabular}

$\mathrm{HW}-10=$ Finger dipped for $10 \mathrm{~min}$ in Hot Water at $100^{\circ} \mathrm{C}, \mathrm{HW}-5=$ Finger dipped for 5 min in Hot Water at $100^{\circ} \mathrm{C}$, $C W=$ Finger dipped in Cold Water at ambient temperature of 27-30 $C ; C=C o n t r o l$, finger peeled and dried directly, no treatment.

Values in the same column with different letters are significantly different at $p<0.05$. 
Table 3. Anti-nutrient content of whole flour produced from improved plantain and banana hybrids pulp and peel mixture

\begin{tabular}{lcccccc}
\hline \multicolumn{7}{c}{ Antinutrient (\%) } \\
\hline Cultivars & Saponin & Tannin & Oxalate & Phytate & Cyanide & Phenolic compound \\
\hline PITA 14 & $1.03^{\mathrm{f}}$ & $0.16^{\mathrm{d}}$ & $0.64^{\mathrm{f}}$ & $8.0 \times 10^{-5 \mathrm{~b}}$ & $1.6 \times 10^{-5 \mathrm{c}}$ & $0.06^{\mathrm{a}}$ \\
PITA 17 & $2.9^{\mathrm{a}}$ & $0.16^{\mathrm{d}}$ & $0.75^{\mathrm{d}}$ & $6.0 \times 10^{-5 \mathrm{e}}$ & $1.6 \times 10^{-5 \mathrm{c}}$ & $0.06^{\mathrm{a}}$ \\
PITA 24 & $1.83^{\mathrm{e}}$ & $0.32^{\mathrm{b}}$ & $0.72^{\mathrm{e}}$ & $9.3 \times 10^{-5 \mathrm{a}}$ & $8.0 \times 10^{-5 \mathrm{a}}$ & $0.06^{\mathrm{a}}$ \\
PITA 26 & $1.86^{\mathrm{d}}$ & $0.36^{\mathrm{a}}$ & $0.88^{\mathrm{a}}$ & $7.9 \times 10^{-5 \mathrm{c}}$ & $1.2 \times 10^{-5 \mathrm{~d}}$ & $0.04^{\mathrm{b}}$ \\
BITA3 & $1.97^{\mathrm{c}}$ & $0.09^{\mathrm{e}}$ & $0.77^{\mathrm{c}}$ & $3.5 \times 10^{-5 \mathrm{f}}$ & $4.0 \times 10^{-5 \mathrm{~b}}$ & $0.06^{\mathrm{a}}$ \\
AGBAGBA & $2.67^{\mathrm{b}}$ & $0.3^{\mathrm{c}}$ & $0.82^{\mathrm{b}}$ & $6.3 \times 10^{-5 \mathrm{~d}}$ & $8.0 \times 10^{-5 \mathrm{a}}$ & $0.06^{\mathrm{a}}$ \\
\hline
\end{tabular}

Values in the same column with different letters are significantly different at $p<0.05$.

Table 4. Heavy metal content of whole flour produced from improved plantain and banana hybrids pulp and peel mixture

\begin{tabular}{llll}
\hline & & \multicolumn{2}{l}{ Heavy metals $(\mathrm{ppm})$} \\
\hline Cultivars & Lead & Cadmium & Mercury \\
& & & \\
PITA 14 & $0.08^{\mathrm{c}}$ & $0.02^{\mathrm{c}}$ & $<0.01^{\mathrm{a}}$ \\
PITA 17 & $0.08^{\mathrm{c}}$ & $0.03^{\mathrm{b}}$ & $<0.01^{\mathrm{a}}$ \\
PITA24 & $0.03^{\mathrm{d}}$ & $0.03^{\mathrm{b}}$ & $<0.01^{\mathrm{a}}$ \\
PITA26 & $0.14^{\mathrm{a}}$ & $0.03^{\mathrm{b}}$ & $<0.01^{\mathrm{a}}$ \\
BITA3 & $0.11^{\mathrm{b}}$ & $0.03^{\mathrm{b}}$ & $<0.01^{\mathrm{a}}$ \\
AGBAGBA & $0.14^{\mathrm{a}}$ & $0.04^{\mathrm{a}}$ & $<0.01^{\mathrm{a}}$ \\
\hline
\end{tabular}

Values in the same column with different letters are significantly different at $p<0.05$. 


\section{REFERENCES}

Adaikpoh, E.O., Nwajei, G.E. and Ogala, J.E. (2005). Heavy metals concentrations in coal and sediments from River Ekulu in Enugu, CoalCity of Nigeria. Journal of Applied Sciences and Environmental Management, 9(3): 5-8.

Adeniji, T.A. (1995). Recipe for plantain/banana wine. MusAfrica 8: 23-24.

Adeniji, T.A. and Empere, C.E. (2001). The development, production and quality evaluation of cake made from cooking banana flour. Global Journal of Pure and Applied Sciences, 7 (4): 633 635.

Adeniji, T.A., Barimalaa, I.S. and Achinewhu, S.C. (2006). Evaluation of Bunch Characteristics and Flour Yield Potential in Black Sigatoka resistant Plantain and Banana Hybrids. Global Journal of Pure and Applied Sciences, 12 (1): 41-43.

Ahenkora, K., Kyei, M.A., Marfo, E.K. and Banful, B. (1996). Nutritional composition of False Horn Apantu pa plantain during ripening and processing. African Crop Science Journal, 4 (2): 243-247.

Allen, S.E., Grimshaw, H.M, Parkinson, J.A. \& Quarmby, C. (1984). Chemical analysis of ecological materials. Edited by S.E. Allen. Blackwell Scientific Publications, Oxford London, Edinburgh, Melbourne, p 565.

Ankrah, E.K. (1974). Chemical studies of some plant wastes from Ghana. Journal of the Science of Food and Agriculture. 25: 1229-1232.

AOAC (1990). Official Methods of Analysis, Washington DC, USA: Association of Official Analytical Chemists.
Apena, A., Amore, T.O., and Shaibu, N. (2004). Nutrient and antinutrient composition of Vernonia amygdalina (bitter leaf). In: (G.O. Adegoke, L.O. Sanni, K.O. Falade and P.I. Uzo-Peters, eds.). Current challenges in the food industry in Nigeria, Proceedings of the $28^{\text {th }}$ annual conference/AGM, Nigerian Institute of Food Science and Technology, University of Ibadan, Ibadan Nigeria, 12-14 October, p164.

Baiyeri, K.P. (2000). Effect of nitrogen fertilization on mineral concentration in plantain (Musa sp. AAB) fruit peel and pulp at unripe and ripe stages. Plant Product Research Journal, 5: 38-43.

Baiyeri, K.P. and Ortiz, R. (2000). Agronomic evaluation of plantain and other triploid Musa. In K. Craenen, R. Ortiz, E.B. Karamura, and D.R. Vuylsteke (eds.). Proceeding of First International Conference of Banana and Plantain in Africa, Kampala, Uganda, 12-18 October, 1996. International Society for Horticulturae, 540: 125135.

Baiyeri, K.P. and Unadike, G.O. (2001). Ripening stages and days after harvest influenced some biochemical properties of two Nigerian plantains (Musa species AAB) cultivars. Plant Product Research Journal, 6: 11-19.

Berry, C.J.J. (1992). First steps in winemaking. Argus Book, England, Eighth edition, p235.

Chandler, S. (1995). The nutritional value of bananas. In: Gowen, S. (ed.). Bananas and Plantains. Chapman and Hall, 2-6 Boundary Row, London SE1 8HN, UK, p. 597.

Chukwu, U., Olorunda, A.O. Adeniji, T.A. Amos, $\mathrm{N}$ and Ferris, R.S.(1998). Development, Production, Properties, and Acceptability of Snacks and Weaning Food Made from Extruded Cooking 
Banana (ABB). In: (R.S.B. Ferris, ed.). Postharvest Technology and Commodity Marketing. Proceedings of a Postharvest Conference on Technology and Commodity Marketing in West Africa, Accra, Ghana. Published by the International Institute of Tropical Agriculture (IITA) Ibadan, Nigeria, p. 120-131.

Duhan, A.B.M., Chauhan, D. and Kapoor, A.C. (1989). Phytic acid contents of chickpea and black gram. Varietal difference and effect of domestic processing and cooking methods. Journal of the Science of Food and Agriculture, 49: 449-455.

Duncan, A.J., Frutos, P. and Young, S.A. (2000). The effect of rumen adaptation of Oxalic acid on selection of oxalic-acid-rich plants by goats. British J. Nutrition, 83: 59-65.

Edelmiro, J.R-S., Miguel, A.G., Isabel B.de Caloni and Orlando, P-R. (1977). The preparation of green banana flour. Journal of Agriculture, University of Puerto Rico, 61 (2), 470-478.

FAO (1989). Prevention of postharvest food losses; fruits, vegetables, and root crops; and training manual. FAO. Code 17, J11: 1-3.

Ganry, J (1990). Quelques indications sur la production et la consommation de bananas et plantains dans le monde. Fruits, numéro spécial, $p$. 17-18.

Ihediomanma, N.C., Ubaonnu, C.N., Akobundu, E.N.T., and Banigo, E.O.I. (2004). Some antinutritional factors associated with pumpkin (Curcurbita pepo) seeds. In: (G.O. Adegoke, L.O. Sanni, K.O. Falade and P.I. Uzo-Peters, eds.). Current challenges in the food industry in Nigeria, Proceedings of the $28^{\text {th }}$ annual conference/AGM, Nigerian Institute of Food Science and Technology,
University of Ibadan, Ibadan Nigeria, 12-14 October, p164.

Izonfuo, W.A.L. and Omuaru, V.O.T. (1988). Effect of Ripening on the Chemical Composition of Plantain Peels and Pulps (Musa paradisiaca). Journal of the Science of Food and Agriculture. 45: 333-336.

Ketiku, A.O. (1973). Chemical composition of unripe (green) and ripe plantain (Musa paradisiaca). Journal of the Science of Food and Agriculture. 24: 703-707.

Lescot, T. (1993). La culture du bananier plantain en Colombie et dans les pays andins. Fruits, 48 (2): 107-114.

Mahato, S.B., Ganguly, A.N., and Sahu, N.P. (1982). Review-Steroid Saponins. Phytochemistry, 21 (5): 959-978.

Merck Index (1976). $9^{\text {th }}$ edn, M. Merck, Rahway, p. 8120 .

Ngalani, J.A. and Crouzet, J. (1995). Utilisation de la farine de banane plantain dans la fabrication des pains, biscuits et farines intantanées. Cahiers Agricultures 4: 61-64.

Noonan, S.C., and Savage, G.P. (1999). Oxalic acid and its effects on humans. Asia Pacific Journal of Clinical Nutrition, 8: 64-74.

Oakenfull, D.G., Fenwick, D.E., Hood, R.L., Topping, D.L., Illman, R.J. and Storer, G.B. (1979). Effects of saponins on bill acids and plasma lipids in the rat. Br. J. Nutr., 42: 209-16.

Ogazi, P.O. (1998). Plantain storage and processing. In: (R.S.B. Ferris, ed.). Postharvest Technology and Commodity Marketing. Proceedings of a Postharvest Conference on Technology and 
Commodity Marketing in West Africa, 29 Nov. to 1 Dec., Accra, Ghana. Published by the International Institute of Tropical Agriculture (IITA) Ibadan, Nigeria, p. 108-119.

Ogazi, P.O. and Jones, M.C. (1990). Pilot-scale dehydration of plantain pulp for flour production using cabinet dryer. Nigerian Food Journal, 8: 74-77.

Onning, G., Wang, Q., Westrom, B. , and Karlsson, B. (1996). Influence of Oat Saponins on Intestinal Permeability in Vitro and in vivo in the rat. British J. Nutrition, 76: 141-151.

Rahman, A.R. (1963). Economical method for the production of flour from green plantains. Journal of Agriculture of the University of Puerto Rico, 47 (1): 1-10

SAS (2003). Statistical Analysis Software (SAS) Systems for Windows, SAS Institute Inc., Cary, NC, USA.

Topping, D.L., Stover, G.B., Calvert, G.D. \& Meller, R.A. (1980). Effects of dietary saponins on fecal bile acids and neutral sterols, plasma lipids and lipoprotein turnover in the pig. Am. J. Clin. Nutr. 33: 783-786.

Ukhum, M.E. and Ukpebor, I.E. (1991). Production of instant plantain flour, sensory evaluation and physico-chemical changes during storage. Food Chemistry, 42: 287-299.

United Nations (1991). African Statistical Yearbook, Volume 2, Part 4: Central Africa. Van der Poel, A.F.B. (1990). Effect of processing on antinutritional factors and protein nutritional value of dry beans. AnimalFeed Science and Technology, 2: 179-208.

Wordu, G.O. (2004). Heavy metals in some seafoods obtained from Rivers State waters. In: (G.O. Adegoke, L.O. Sanni, K.O. Falade and P.I. Uzo-Peters, eds.). Current challenges in the food industry in Nigeria, Proceedings of the $28^{\text {th }}$ annual conference/AGM, Nigerian Institute of Food Science and Technology, University of Ibadan, Ibadan Nigeria, 12-14 October. 